\title{
Alterations of Neuroretinal and Corneal Thickness in Hashimoto's Thyroiditis
}

\author{
Osman Okan Olcaysü ${ }^{1}$ (D) , Buğra Karasu ${ }^{2}$ (D) , Elif Olcaysü ${ }^{3}$ (D) , Atilla Çayır ${ }^{3}$ (DD, \\ Ali Rıza Cenk Çelebi ${ }^{4}$ iD
}

${ }^{1}$ Bakırköy Sadi Konuk Eğitim ve Araştırma Hastanesi Göz Hastalıkları, İstanbul, Türkiye

${ }^{2}$ Göz Hastalıkları Kliniği, İstanbul Tuzla Hastanesi, İstanbul, Türkiye

${ }^{3}$ Bakırköy Sadi Konuk Eğitim ve Araştırma Hastanesi Çocuk Sağlığı ve Hastalıkları, İstanbul, Türkiye

${ }^{4}$ Acıbadem Mehmet Ali Aydınlar Üniversitesi, Atakent Eğitim ve Araştırma Hastanesi Göz Kliniği, İstanbul, Türkiye

Osman Okan OLCAYsü

Buğra KARASU

Elif OLCAYSÜ

Atilla ÇAYIR

Ali Rıza Cenk ÇELEBi

\section{Correspondence: Buğra Karasu}

İstanbul Tuzla Devlet Hastanesi, Göz Hastalıkları Kliniği, İstanbul, Türkiye

Phone: +905493825082

E-mail: bugra karasu@hotmail.com

\section{ABSTRACT}

Purpose:To compare changes in macula, retinal nerve fiber layer (RNFL) and central corneal thickness (CCT) in patients with Hashimoto's thyroiditis (HT) with age-matched healthy control group.

Materials and Methods: This study was conducted with a prospective, observational, cross-sectional design. The individuals participating in the study were divided into 2 groups: patients with a diagnosis of HT (group 1, n:54 eyes) and age-matched healthy participants (group 2, n:70 eyes). Corneal, retinal and macular thickness measured by optical coherence tomography. Mean outcome measurements were CCT, intra-ocular pressure (IOP), central $1 \mathrm{~mm}$ foveal thickness (CFT), subfoveal choroidal thickness (SFCT), total macular volume (TMV), central $1 \mathrm{~mm}$ foveal volume (CFV), and RNFL thickness in superior, nasal, inferior and temporal quadrants.

Results:The mean IOP was $17.07 \pm 2.34 \mu \mathrm{m}$ in group 1 and $14.20 \pm 2.76 \mu \mathrm{m}$ in group 2 , respectively $(\mathrm{p}<0.001)$. Mean $\mathrm{CCTs}$ were $539.44 \pm 35.27 \mu \mathrm{m}$ and $555.06 \pm 40.53 \mu \mathrm{m}(\mathrm{p}=0.001)$, CFTs were $227.35 \pm 17.52 \mu \mathrm{m}$ and $230.38 \pm 23.52 \mu \mathrm{m}(\mathrm{p}=0.57)$, SFCT were $210,79 \pm 20,13 \mu \mathrm{m}$ and $268,47 \pm 24,56 \mu \mathrm{m}(\mathrm{p}<0.001)$, TMV s were $7.16 \pm 0.35 \mathrm{~mm} 3$ and $7.02 \pm 0.26 \mathrm{~mm} 3(\mathrm{p}=0.07)$, CFVs were $0.17 \pm 0.01 \mathrm{~mm} 3$ and $0.19 \pm 0.07 \mathrm{~mm} 3(p=0.16)$ in group 1and group 2, respectively. RNFL thickness values were significantly thinner in the group $1(p<0.05)$ in all quadrants except for the nasal quadrant $(p=0.086)$.

Conclusion:Hypothyroidism secondary to $\mathrm{HT}$ may be a determining factor affecting the development of the cornea and retina. Elevated IOP and decrement of RNFL thickness in children with $\mathrm{HT}$ increased the risk of developing glaucoma, as well as decreased SFCT may predispose to the development of chorioretinal disorders in the future.

Keywords:Corneal thickness, Hashimoto's thyroiditis, retinal nerve fiber layer thickness, macula

\section{Hashimoto Tiroiditinde Nöroretinal ve Kornea Kalınlığındaki Değișiklikler}

ÖZET

Amaç: Hashimoto tiroiditi (HT) olan hastalarda makula, retina sinir lifi tabakası (RSLT) ve santral kornea kalınlığındaki (SKK) değişiklikleri yaşa uygun sağlıklı kontrol grubu ile karşılaştırmak.

Hastalar ve Yöntemler: Bu çalışma prospektif, gözlemsel, kesitsel dizayn ile yapıımışıı. Çalışmaya katılan bireyler 2 gruba ayrıldı: HT tanısı olan hastalar (grup 1, n: 54 göz) ve yaşları eşleștirilmiş sağlıklı katılımcılar (grup 2, n: 70 göz). Optik koherens tomografi (OKT) ile kornea, retina ve maküler kalınlıklar ölçüldü. Ortalama sonuç ölçümleri SKK, göz içi basıncı (GiB), merkezi $1 \mathrm{~mm}$ foveal kalınlık (MFK), subfoveal koroid kalınlığı (SFKK), toplam maküler hacim (TMH), santral $1 \mathrm{~mm}$ foveal hacim (SFH) ve üst, nazal, alt ve temporal kadranlardı.

Bulgular: Ortalama GiB grup 1'de 17.07 $\pm 2.34 \mu \mathrm{m}$, grup 2'de 14.20 $\pm 2.76 \mu \mathrm{m}$ idi ( $<<0.001)$. Ortalama SKK'lar $539.44 \pm$ $35.27 \mu \mathrm{m}$ ve $555.06 \pm 40.53 \mu \mathrm{m}(p=0.001)$, SFK'lar $227.35 \pm 17.52 \mu \mathrm{m}$ ve $230.38 \pm 23.52 \mu \mathrm{m}$ ( $p=0.57)$, SFKK 210,79 \pm $20,13 \mu \mathrm{m}$ ve $268,47 \pm 24,56 \mu \mathrm{m}$ idi Grup 1 ve grup 2'de sirasiyla, $(p<0.001)$, TMH'lar $7.16 \pm 0.35 \mathrm{~mm} 3$ ve $7.02 \pm 0.26 \mathrm{~mm} 3$ $(p=0.07)$, CFV'ler $0.17 \pm 0.01 \mathrm{~mm} 3$ ve $0.19 \pm 0.07 \mathrm{~mm} 3(p=0.16)$ idi. Grup 1'de RSLT kalınlık değerleri, nazal kadran hariç tüm kadranlarda anlamlı olarak daha ince bulundu $(p<0.05)(p=0.086)$.

Sonuç: HT'ye bağlı hipotiroidizm, kornea ve retinanın gelişimini etkileyen belirleyici bir faktör olabilir. HT'li çocuklarda yüksek GiB ve RSLT kalınlığının azalması, glokom gelişme riskini artırdığı gibi, azalmış SFKK de gelecekte korioretinal bozuklukların gelişimine yatkınlık yaratabilir.

Anahtar Kelimeler: Kornea kalınlığı, Hashimoto tiroiditi, retina sinir lifi tabakası, makula 
$\mathrm{H}$ ashimoto's thyroiditis (HT) was firstly described by Hakaru Hashimoto in 1912 which had explained by pathological mechanism as: the thyroid gland is attacked by antibody-mediated immune processes (1). Thyroid function varies from euthyroidism to thyrotoxicosis. With the development of hypothyroidism in patients, the enlarged thyroid gland generally undergoes atrophy (2). No information on the pathogenesis of HT was known until 1956. Rose et al. have reported thyroglobulin antibodies and thyroiditis in rabbits which immunized with thyroid extract (3). Thyroid hormone (TH) plays a critical role in eye embryogenesis, but its effect on the development of cornea and neuroretinal tissue is not fully understood. TH can cause a wide variety of effects on different neural tissues, including proliferation, differentiation, and migration (4). There are several studies in the literature with conflicting results investigating the relationship between hypothyroidism and retino-choroidal or corneal changes, as well as ocular alterations (5-7). Herein, we aimed to investigate macular thickness, subfoveal choroidal thickness (SFCT), central corneal thickness (CCT), and retinal nerve fiber layer (RNFL) thickness in the patients with the diagnosis of hypothyroidism due to HT and compare the results with healthy age-matched control group.

\section{MATERIALS AND METHODS}

This prospective, single-center clinical study was conducted in the ophthalmology clinic of a tertiary hospital in collaboration with the endocrinology clinic between January 2015 and February 2018. The study conformed to the tenets of the Declaration of Helsinki and was approved by the Research Ethics Committee. Informed written consent was obtained from each participant. Patients with any sign of orbitopathy, corneal pathology, glauco$\mathrm{ma}$, and retinal vascular disease such as diabetic or hypertensive retinopathy were excluded from the study. The patients who had the diagnosis of hypothyroidism due to $\mathrm{HT}$ in the outpatient clinic of the endocrinology department were enrolled as study group. Healthy age-matched participants constituted as the control group. Individuals with $\mathrm{HT}$ are in remission and under strict monitoring. A complete ophthalmic examination including visual acuity with Snellen chart, intraocular pressure measurement (IOP) (Goldmann applanation), anterior segment and fundus examinations, measurements of corneal, macular, SFCT and RNFL thickness were performed for each patient. CCT measurements were implemented by optical coherence tomography (OCT) (Optovue Avanti ${ }^{\circledast}$ ). The mean of three sequential measurements from the central cornea was utilized for the assessment. RNFL thickness were measured by spectral domain optical coherence tomography (SD-OCT) (Optovue Avanti ${ }^{\oplus}$ Inc., Fremont, CA, USA). The SD-OCT assessments were performed in a dim room after mydriasis with tropicamide $0.5 \%$ drops by one of the authors (OOO). Mean outcome measures were central foveal thickness (CFT), mean SFCT, total macular volume (TMV), central foveal volume (CFV), and the RNFL thickness in the superior, nasal, inferior and temporal quadrants calculated automatically by SD-OCT. Subfoveal choroidal thickness were measured by the enhanced depth image optical coherence tomography (EDI-OCT) imaging method described by Spaide et al (8). SFCT was characterized as the vertical distance from the basal edge of retinal pigment epithelium below the central fovea to the endpoint of the choroid-scleral junction. Figure 1 shows EDIOCT and mapping of the macula measurements on eyes with HT. Figure 2 shows optic nerve head measurements from an healthy individual. Figure 3 demonstrates the CCT measurement of a healthy individual.

\section{Statistical analysis}

The data was analyzed by using the Statistical Package for Social Science (SPSS) programme (SPSS version 15.0 for Windows; SPSS, Chicago, IL). Levene test for equality of variances and t test for equality of means were used for the comparison of the groups. P value of $<0.05$ was considered as statistically significant.

\section{RESULTS}

Twenty-seven participants with 54 eyes that female:male ratio was 12:15 in group 1 and 35 participants with 70 eyes that female:male ratio was 16:19 in group 2 were included in study. There was no statistically significant difference in demographic data between the groups $(p>0.05)$. The mean age was $12.4 \pm 1.3$ years (range, 9-14 years) in group 1, and 11.9 \pm 1.4 years (range, 7-14 years) in group 2. The mean weight and height were $36.9 \pm 8.4 \mathrm{~kg}$ and $146.3 \pm 15.2 \mathrm{~cm}$ in group $1 ; 37.7 \pm 7.6 \mathrm{~kg}$ and $147.4 \pm 13.9$ $\mathrm{cm}$ in group 2. Descriptive characteristics (age, weight, height, gender distribution) of each groups are shown in Table 1. The mean CCT was $539.44 \pm 35.27 \mu \mathrm{m}$ in group 1 and $555.06 \pm 40.53 \mu \mathrm{m}$ in group $2(p=0.001)$. The mean IOP was $17.07 \pm 2.34 \mu \mathrm{m}$ in group 1 and $14.20 \pm 2.76 \mu \mathrm{m}$ in group $2(p<0.001)$. The mean CFT was $227.35 \pm 17.52 \mu \mathrm{m}$ in group $1,230.38 \pm 23.52 \mu \mathrm{m}$ group $2(\mathrm{p}=0.001)$. Mean SFCT was $210.79 \pm 20.13 \mu \mathrm{m}$ in group $1,268.47 \pm 24.56$ $\mu \mathrm{m}$ group $2(p<0.001)$. Mean TMVs were $7.16 \pm 0.35 \mathrm{~mm} 3$ and $7.02 \pm 0.26 \mathrm{~mm} 3(\mathrm{p}=0.07), \mathrm{CFV}$ s were $0.17 \pm 0.01 \mathrm{~mm} 3$ and $0.19 \pm 0.07 \mathrm{~mm} 3$ in group 1 and group 2, respectively $(p=0.16)$. 


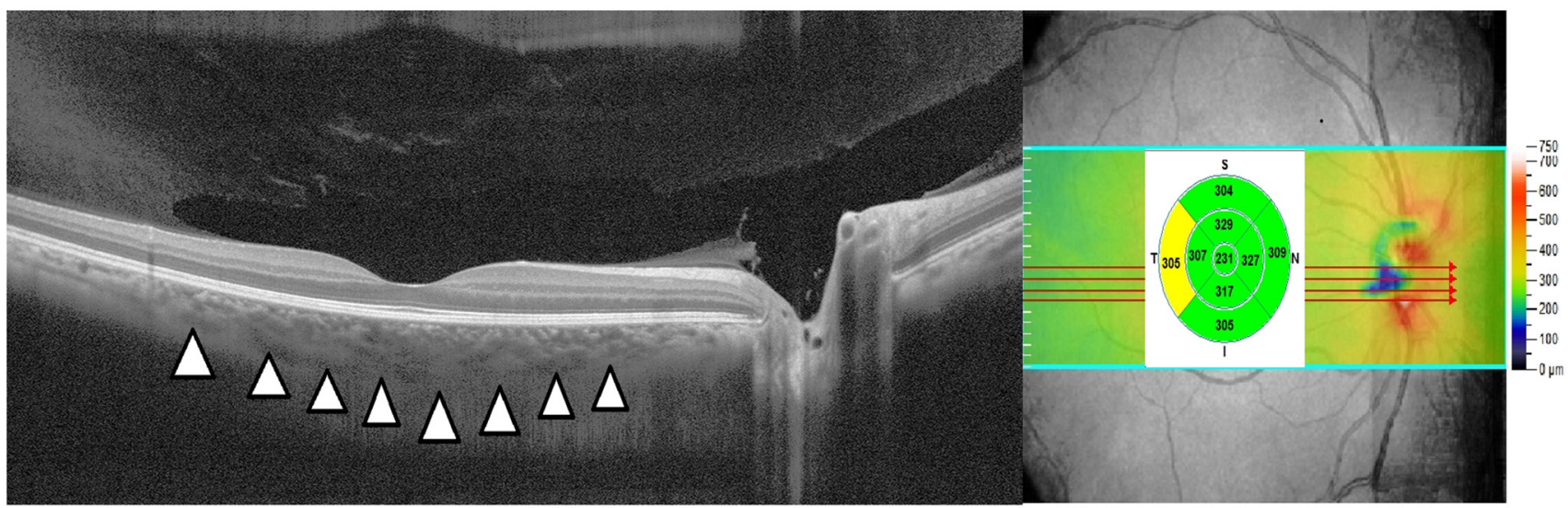

Figure 1. Enhanced optical coherence tomography (EDI-OCT) and mapping of the macula in eyes with Hashimoto's thyroiditis are shown. White arrows show the choroidal-scleral junction and its border.

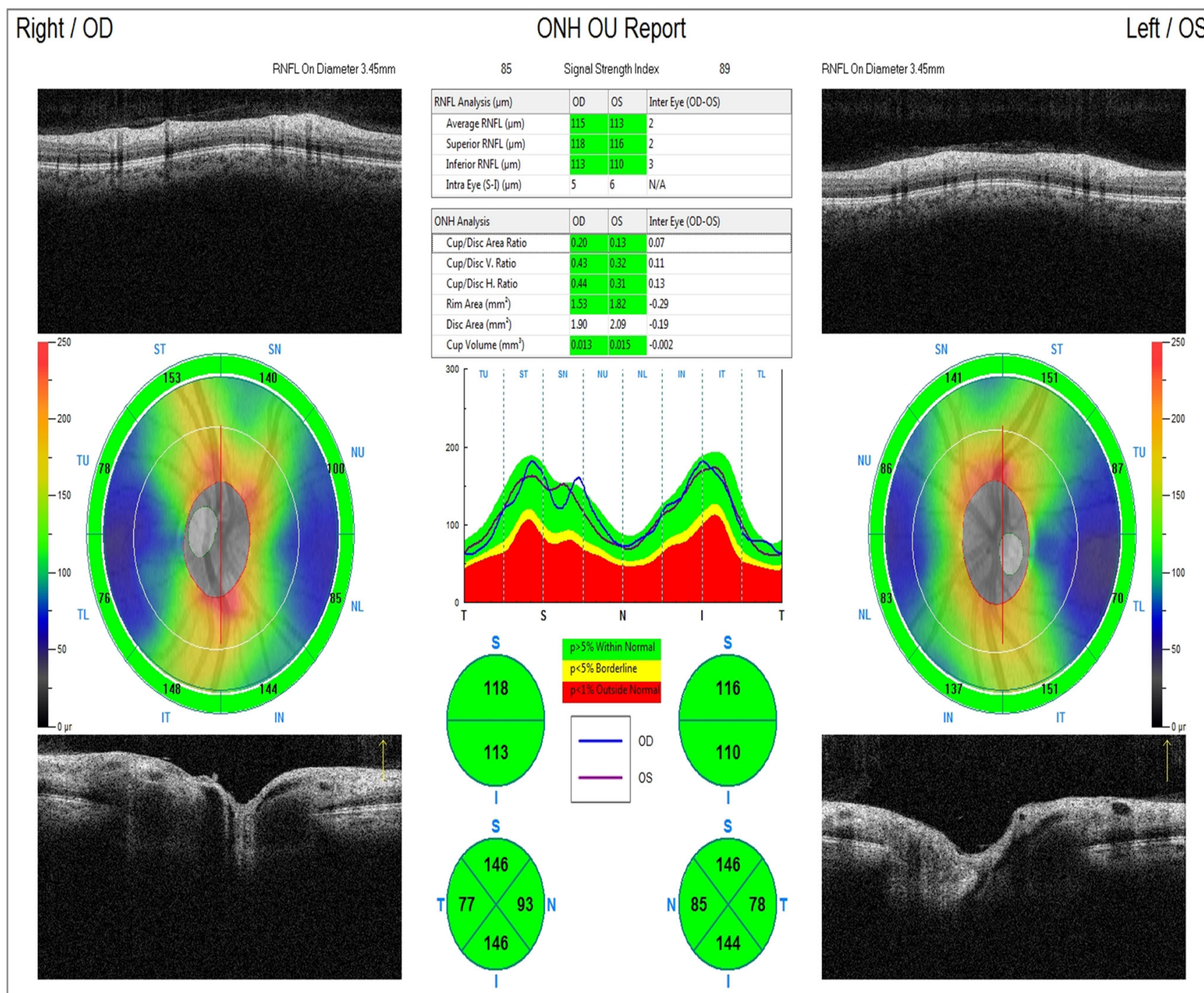

Figure 2. The optic nerve head (ONH) measurements of a healthy individual are shown. 

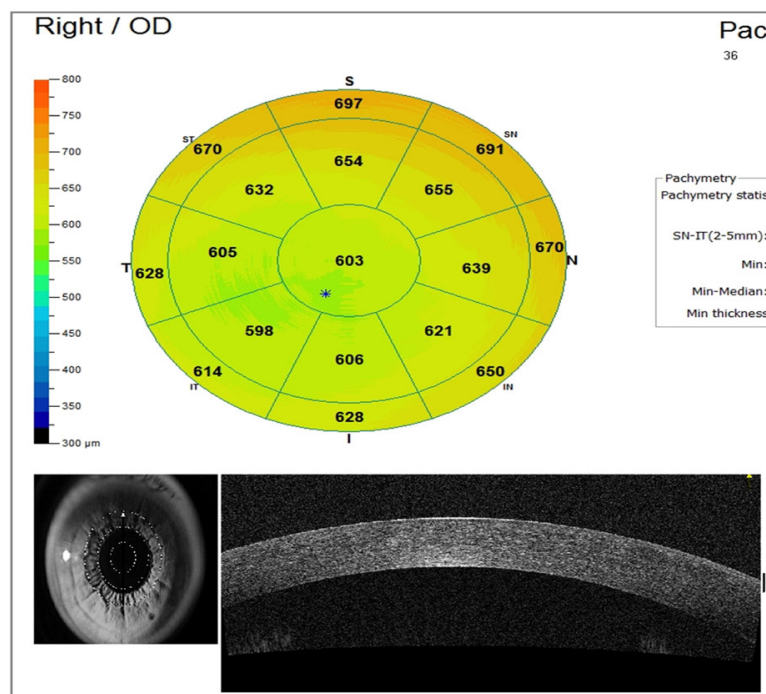

Pachymetry OU Report

Signal Strength Index

Pachymetry Map
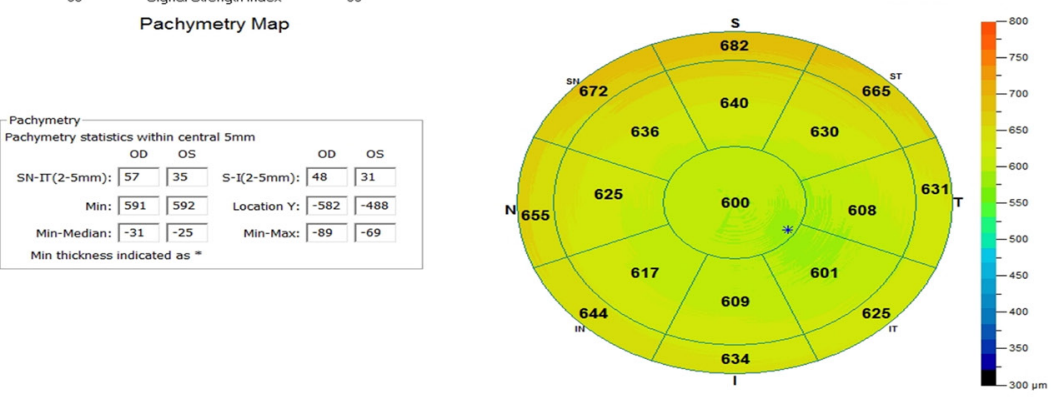

Figure 3. The image of central corneal thickness (CCT) measurement of a healthy individual was displayed.

\begin{tabular}{|c|c|c|c|}
\hline Mean $\pm S D$ & $\begin{array}{c}\text { Group } 1 \\
\text { Hashimoto } \\
\text { group } \\
(n=54)\end{array}$ & $\begin{array}{c}\text { Group } 2 \\
\text { Control Group } \\
(n=70)\end{array}$ & $\begin{array}{l}p \\
\text { values }\end{array}$ \\
\hline Age (years) & $\begin{array}{c}12.4 \pm 1.3(9-14 \\
\text { years })\end{array}$ & $\begin{array}{c}11.9 \pm 1.4(7-14 \\
\text { years })\end{array}$ & 0.879 \\
\hline Weight (kg) & $36.9 \pm 8.4$ & $37.7 \pm 7.6$ & 0.745 \\
\hline Height (cm) & $146.3 \pm 15.2$ & $147.4 \pm 13.9$ & 0.912 \\
\hline Male/Female (n) & $15 / 12$ & $19 / 16$ & 0.749 \\
\hline
\end{tabular}

The results of the study are summarized in Table 2. As for RNFL measurements, mean RNFL thicknesses in central, superior, inferior, nasal and temporal quadrants were $109.40 \pm 12.50 \mu \mathrm{m}, 130.72 \pm 16.38 \mu \mathrm{m}, 139.42 \pm 17.60$ $\mu \mathrm{m}, 81.14 \pm 9.51 \mu \mathrm{m}$, and $72.18 \pm 8.08 \mu \mathrm{m}$ in group 1 , and $115.41 \pm 12.80 \mu \mathrm{m}, 141.65 \pm 17.48 \mu \mathrm{m}, 156.25 \pm 17.96 \mu \mathrm{m}$, $80.67 \pm 11.84 \mu \mathrm{m}$, and $76.81 \pm 12.43 \mu \mathrm{m}$ in group $2(\mathrm{p}=0.019$, $p=0.048, p=0.014, p=0.86$ and $p=0.028)$. RNFL thickness analysis of the study are given in Table 3 . Figure 4 shows graphic of the results in the study.

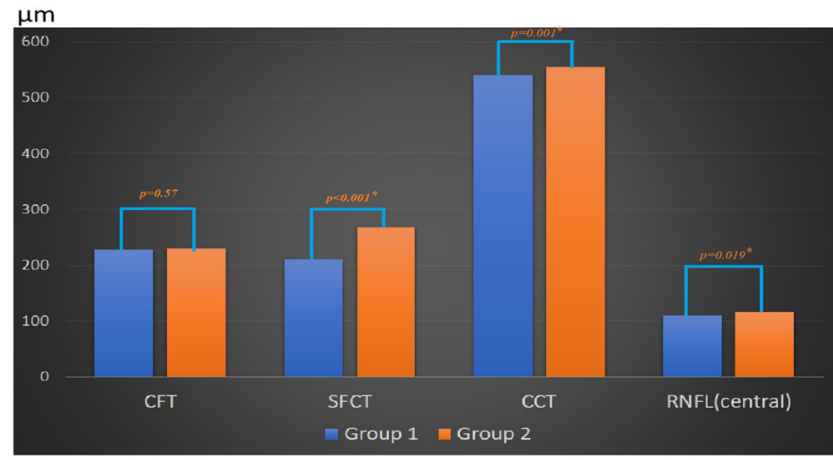

Figure 4. The graphic of the results is summarized in the study. 
Table 3. Retinal nerve fiber layers analysis of the study

\begin{tabular}{|c|c|c|c|}
\hline Mean \pm SD & $\begin{array}{c}\text { Group 1 } \\
\text { Hashimoto Group } \\
(\mathbf{n = 5 4 )}\end{array}$ & $\begin{array}{c}\text { Group 2 } \\
\text { Control Group } \\
(\mathbf{n = 7 0 )}\end{array}$ & $\boldsymbol{p}$ values \\
\hline Mean RNFL central, $\boldsymbol{\mu m}$ & $109.40 \pm 12.50$ & $115.41 \pm 12.80$ & $\mathbf{0 . 0 1 9 ^ { * }}$ \\
\hline Mean RNFL superior, $\boldsymbol{\mu m}$ & $130.72 \pm 16.38$ & $141.65 \pm 17.48$ & $\mathbf{0 . 0 4 8}^{*}$ \\
\hline Mean RNFL inferior, $\boldsymbol{\mu m}$ & $139.42 \pm 17.60$ & $156.25 \pm 17.96$ & $\mathbf{0 . 0 1 4}^{*}$ \\
\hline Mean RNFL & $81.14 \pm 9.51$ & $80.67 \pm 11.84$ & $\mathbf{0 . 8 6}^{*}$ \\
\hline nasal, $\boldsymbol{\mu m}$ & $72.18 \pm 8.08$ & $76.81 \pm 12.43$ & $\mathbf{0 . 0 2 8}^{*}$ \\
\hline Mean temporal RNFL, $\mu \mathrm{m}$ & & & \\
\hline
\end{tabular}

\section{DISCUSSION}

Hypothyroidism is second common endocrine disorder following diabetes mellitus (9). HT is also known as chronic lymphocytic thyroiditis, chronic autoimmune thyroiditis, and lymphadenoid goiter. Most patients with HT are euthyroid or have subclinical hypothyroidism with goiter and circulating thyroid antibodies. As time passes, overt hypothyroidism will develop at a rate of about $5 \%$ per year (2). The specific factor initiating autoimmunity to thyroid antigens is a dilemma. Similar to other autoimmune diseases, HT is assumed to appear from a breakdown of selftolerance to thyroid antigens (10). Latest studies have focused attention on many contributor to the increased risk such as; vitamin D receptor gene polymorphisms (11), interleukin 6 gene promoter polymorphism (12), polymorphism in the interferon gamma gene (13), T cell receptor restriction fragment length polymorphism (14), specific allotypes of the immunoglobulin G heavy chain (15), CT 60 polymorphism of cytotoxic T-lymphocyte-associated protein-4 maps (16), and X chromosome inactivation (17). Thyroid hormone is crucial for the normal development of the central nervous system (18). Clinical and experimental studies have focused attention on the role played by $\mathrm{TH}$ also in neuroretinal development. However, knowledge on $\mathrm{TH}$ mechanisms on the developing visual system is still uncompleted. Recently, many studies have demonstrated the implication of TH in cone differentiation during the retinal development, growth and regeneration (19). Visual system morphogenesis and functioning rely on the accurate location of specific cells and the formation of relevant intercellular connections (20,21). Pinazo-Duran et al. investigated the role of $\mathrm{TH}$ in the developing retina and optic nerve, in a rat model of controlled TH deficiency. They reported that a depletion in the volume of the eye $(p<0.001)$ and optic nerve cross- sectional zone $(p<0.001)$, attenuation of the retinal layers $(p<0.001)$, and remarkably postponed glial development and myelination in the TH defiency optic nerves $(p<0.001)$, as compared to controls (22). Durieux et al. investigated electroretinogram (ERG) findings in three hypothyroid adult dogs with and without levothyroxine treatment, and reported that a dose of $20 \mu \mathrm{g} / \mathrm{kg}$ of levothyroxine given to adult dogs was associated with a noticeable peak time shortening of both photopic and scotopic ERGs (23). Ittermann et al. used data from 3189 individuals and investigated association between serum thyrotropin (TSH) levels and retinal artery narrowing and defined by arterio-venous ratio from static vessel analysis. They reported that high serum TSH levels were accompanied by retinal arteriolar narrowing, and described potential mechanisms by long-term hypertension, atherosclerotic processes, and inflammation (24). Studies about the effects of thyroid disorders on central corneal thickness are still unsatisfactory. The implication of TH in corneal physiology is being investigated in some studies. Conrad et al. reported the presence of thyroxin receptors alpha and beta in the chicken cornea (25). Bahceci et al. demonstrated a significant increase in CCT in hypothyroid patients that could be reversed with thyroxine replacement medication. Additionally, they concluded that the prevalence of glaucoma in hypothyroidism might not be as high as they previously reported when IOP was corrected for CCT (26). In the study of Gül et al., it was aimed to compare choroidal thickness in active and stable phases of Hashimoto thyroid eye disease. Subfoveal, temporal macula, nasal macula, temporal peripapillary and nasal peripapillary choroidal thickness measurements were performed in 23 eyes of 23 patients. SFCT was significantly thicker in the group with thyroid eye disease in the active phase than in the group with stable phase disease $(p=0.04)(6)$. In our study, CCT was thicker in patients with $\mathrm{HT}$, and found to be statistically significant difference in CCT among the groups $(p=0.001)$. 
Although similar results were obtained in our study, the sample size and prospective design constituted our superior aspects compared to this study. association between hypothyroidism and open angle glaucoma but none of them evaluate The literature contains controversial results considering the $d$ patients according to etiology. Some studies report an association, whereas others failed to find such an association (27-29). Lin et al. investigated the risk of open-angle glaucoma after a diagnosis of hypothyroidism during the 5 -year follow-up period. Their study group consisted of 257 hypothyroidism patients and the comparison group involved 2056 subjects. They reported that hypothyroidism patients had 1.78-fold greater risk of developing open angle glaucoma. In our study, IOP was higher in patients with $\mathrm{HT}$, and there was statistically significant difference in IOP between the groups $(p=0.002)$ (30). In a study conducted by Kırgız et al., they compared CCT and IOP values of $48 \mathrm{HT}$ and 49 control healthy eyes. Although there was no significant difference in central corneal thickness (CCT) values between the HT group and the control group ( $p=0.65)$, IOP values were significantly higher in HT group $(p=0.001)$ (7). To the best of our knowledge, this study is the first of its kind where individuals with HT were examined for corneal and neuroretinal thicknesses together. Bahceci et al. measured RNFL thicknesses parameters with scanning laser polarimeter and did not find any statistically significant result formed by hypothyroidism (26). Ozturk et al. investigated RNFL thickness of 33 patients diagnosed to have primary hypothyroidism and reported statistically significant change $(p<0.05)$ (31). A statistically significant change was found in mean RNFL thickness among the groups in our study $(p<0.05)$. Limitations of this study are the small sample size, lack of control group and short follow-up period that might affect the statistical power. Advantages of present study are prospective design and detailed statistical parameters. In conclusion, hypothyroidism due to HT may be definitive factor affecting corneal and retinal development as presumed in some previous studies. Therefore, close follow-up and frequent examinations should be prioritized. Future prospective studies involving large subsets may provide further evidence of the susceptibility of $\mathrm{HT}$ to ocular disease.

\section{DISCLOSURE AND ACKNOWLEDGMENTS}

Funding: This research received no specific grant from any funding agency in the public, commercial, or notfor-profit sectors.
Conflict of Interest: No conflicting relationship exists for any author.

Ethical approval: All procedures performed in studies involving human participants were in accordance with the ethical standards of the institutional and/or national research committee and with the 1964 Helsinki declaration and its later amendments or comparable ethical standards.

Informed consent: Informed consent was obtained prior to every surgical procedure from all individual participants included in the study.

\section{REFERENCES}

1. Hashimoto H. Zur Kenntniss der lymphomatösen Veränderung der Schilddrüse (Struma lymphomatosa). Arch Klin Chir 1912; 97:219-50.

2. Vanderpump MPJ. The epidemiology of thyroid disease. In Braverman L.E., and Utiger R.D. (eds): Werner \& Ingbar's the thyroid: a fundamental and clinical text, 9th ed. Philadelphia: Lippincott Williams \& Wilkins; 2005:398-406.

3. Rose NR, Witebsky E. Studies in organ specificity. V. Changes in the thyroid glands of rabbits following active immunisation with rabbit thyroid extracts. J Immunol 1956; 76(6):417-27.

4. Thompson CC, Potter GB. Thyroid hormone action in neural development. Cereb Cortex 2000; 10(10):939-45.

5. Karabulut GO, Fazil K, Ozturker C, et al. Do ocular pulse amplitude and choroidal thickness change in patients with thyroid eye disease? Orbit 2019 Oct;38(5):347-352.

6. Gul A, Basural E, Ozturk HE. Comparison of choroidal thickness in patients with active and stable thyroid eye disease. Arq Bras Oftalmol. 2019 Mar-Apr;82(2):124-128.

7. Kırgız A, Çabuk KS, Yetmis M, et al. Corneal biomechanical properties in patients with Hashimoto's thyroiditis. Adv Clin Exp Med. 2019 Jan;28(1):109-112.

8. Spaide RF, Koizumi H, Pozzoni MC. Enhanced depth imaging spectraldomain optical coherence tomography. Am J Ophthalmol. 2008 Oct;146(4):496-500.

9. Garber JR, Cobin RH, Gharib $\mathrm{H}$, et al. Clinical practice guidelines for hypothyroidism in adults: cosponsored by the American Association of Clinical Endocrinologists and the American Thyroid Association. Endocr Pract. 2012;18(6):988-1028.

10. Nossal GJ, Pike BL. Evidence for the clonal abortion theory of B-lymphocyte tolerance. J Immunol 1975;179(9): 5619-32.

11. Lin WY, Wan L, Tsai CH, et al. Vitamin D receptor gene polymorphisms are associated with risk of Hashimoto's thyroiditis Chinese patients in Taiwan. J Clin Lab Anal 2006; 20: 109-12.

12. Chen RH, Chang CT, Chen WC, et al. Proinflammatory cytokine gene polymorphisms among Hashimoto's thyroiditis patients. J Clin Lab Anal 2006; 20(6):260-5.

13. Ito C, Watanabe M, Okuda N, et al. Association between the severity of Hashimoto's disease and the functional $+874 \mathrm{~A} / \mathrm{T}$ polymorphism in the interferon-gamma gene. Endocr J 2006; 53(4):473-8.

14. Ito $\mathrm{M}$, Tanimoto $\mathrm{M}$, Kamura $\mathrm{H}$, et al. Association of HLA antigen and restriction fragment length polymorphism of $\mathrm{T}$ cell receptor betachain gene with Graves' disease and Hashimoto's thyroiditis. J Clin Endocrinol Metab 1989; 69(1):100-4. 
15. Dussault JH, Ruel J. Thyroid hormones and brain development. Annual Revue of Physiology 1987; 49(1): 321-34.

16. Mader MM, Cameron DA. Photoreceptor differentiation during retinal development, growth, and regeneration in a metamorphic vertebrate. Journal of Neuroscience 2004; 24(50): 11463-72.

17. Yin $X$, Latif $R$, Tomer $Y$, et al. Thyroid epigenetics: $X$ chromosome inactivation in patients with autoimmune thyroid disease. Ann NY Acad Sci 2007; 1110(1):193-200.

18. Mader MM, Cameron DA. Effects of induced systemic hypothyroidism upon the retina: regulation of thyroid hormone receptor alpha and photoreceptor production. Molecular Vision 2006; 12(1): 915-30.

19. Bernal J. Thyroid hormones and brain development. Vitam. Horm. 2005; 71:95-122.

20. Morreale de Escobar, Calvo GR, Obregon MJ, et al. Contribution of maternal thyroxine to fetal thyronine pools in normal rats near term. Endocrinology 1990; 126(5): 2765-7.

21. Santisteban P, Bernal J. Thyroid development and effect on the nervous system. Rev. Endocr. Metab. Disord. 2005; 6(3):217-28.

22. Pinazo-Durán MD, Pons-Vázquez S, Gallego-Pinazo R, et al. Thyroid hormone deficiency disrupts rat eye neurodevelopment. Brain Res. 2011(1); 1392:16-26.

23. Durieux $P$, Rigaudière $F$, Le Gargasson JF, et al. ERG findings in three hypothyroid adult dogs with and without levothyroxine treatment. Vet Ophthalmol. 2008;11(6):406-11.

24. Ittermann T, Dörr M, Völzke $\mathrm{H}$, et al. High serum thyrotropin levels are associated with retinal arteriolar narrowing in the general population. Thyroid. 2014; 24(10):1473-8.

25. Conrad AH, Zhang Y, Walker AR, et al. Thyroxine affects expression of KSPG- related genes, the carbonic anhydrase II gene, and KS sulfation in the embryonic chicken cornea. Invest Ophthalmol Vis Sci. 2006; 47(1):120-32.

26. Bahceci UA, Ozdek S, Pehlivanli Z, et al. Changes in intraocular pressure and corneal and retinal nerve fiber layer thicknesses in hypothyroidism. Eur J Ophthalmol 2005; 15(5): 556-61.

27. Lee AJ, Rochtchina E, Wang JJ, et al. Open-angle glaucoma and systemic thyroid disease in an older population: the Blue Mountains Eye Study. Eye (Lond) 2004; 18(6):600-8.

28. Motsko SP, Jones JK. Is there an association between hypothyroidism and open- angle glaucoma in an elderly population? An epidemiologic study. Ophthalmology 2008; 115(9):1581- 4.

29. Cross JM, Girkin CA, Owsley C, et al.The association between thyroid problems and glaucoma. Br J Ophthalmol 2008; 92(11):1503-5.

30. Lin HC, Kang JH, Jiang YD, et al. Hypothyroidism and the risk of developing open-angle glaucoma: a five-year population-based follow-up study. Ophtalmology 2010 Oct;117(10):1960-6.

31. Ozturk BT, Kerimoglu $\mathrm{H}$, Dikbas $\mathrm{O}$, et al. Ocular changes in primary hypothyroidism. BMC Res Notes. 2009; 2:266. 